\title{
Conformation-Dependent Oligomers in Cerebrospinal Fluid of Presymptomatic Familial Alzheimer's Disease Mutation Carriers
}

\author{
John M. Ringman ${ }^{a}$ Jennifer L. Tomic ${ }^{b}$ Giovanni Coppola ${ }^{a}$ \\ David Elashoffa, ${ }^{a}$ Karen H. Gylys ${ }^{a, d}$ Charles G. Glabe ${ }^{b}$
}

${ }^{a}$ Mary S. Easton Center for Alzheimer's Disease Research at UCLA, ${ }^{b}$ UC Irvine Department of Molecular Biology, ' UCLA Department of Medicine, and d UCLA School of Nursing, Los Angeles, Calif., USA

\section{Key Words}

Presymptomatic · Alzheimer's disease $\cdot$ Oligomer $\cdot A \beta \cdot A \beta 42 \cdot$ Cerebrospinal fluid $\cdot$

Presenilin-1 $\cdot$ Amyloid precursor protein $\cdot$ Conformation

\begin{abstract}
Background/Aims: Oligomerization of amyloid beta $(A \beta)$ is a hypothesized step in the formation of plaques in Alzheimer's disease (AD) but has been difficult to demonstrate in vivo in humans. As persons destined to develop familial AD (FAD) due to fully penetrant autosomal dominant mutations are essentially certain to develop the disease, they provide the opportunity to identify oligomers during the presymptomatic stage of the disease. Methods: We measured levels of $A \beta_{42}$ using a conventional immunoassay and prefibrillar, fibrillar, and annular protofibrillar oligomers using polyclonal conformation-dependent antibodies in the cerebrospinal fluid (CSF) of 7 persons at risk for inheriting FAD mutations. Levels of oligomers were compared between FAD mutation carriers and noncarriers. Results: Compared to 2 noncarriers, annular protofibrillar oligomers were elevated, prefibrillar and fibrillar oligomers trended towards elevation and $A \beta_{42}$ monomer trended towards being decreased in 5 FAD mutation carriers. Conclusion: Our data provide evidence for an identifiable elevation of CSF oligomers during the presymptomatic phase of FAD.
\end{abstract}

Copyright $\odot 2012$ S. Karger AG, Basel

\section{Introduction}

The 'amyloid hypothesis' of the pathogenesis of Alzheimer's disease (AD) posits that an increased production or a decreased degradation of derivatives of the amyloid precursor protein (APP) initiate a cascade of events that cause the illness [1]. This hypothesis is based in 
Presymptomatic Familial Alzheimer's Disease Mutation Carriers

part on the observation that causative autosomal dominant familial AD (FAD) mutations cause absolute or relative increases in the amount of the 42 -amino acid length version of the peptide produced by cleavage of APP $\left(A \beta_{42}\right)$ [2]. Also, the amyloid plaques in the brain that define the illness are largely composed of derivatives of APP, and the deposition of $A \beta_{42}$ is an early event in their formation [3]. However, there is an imperfect association between the degree of amyloid deposition and patient clinical status, and intervention studies have suggested that it may be possible to decrease plaque pathology without significant impact on the disease course [4]. There has been an increasing focus on soluble forms of $A \beta$ as being more crucial to the development of $\mathrm{AD}$ than the plaques per se, with various forms of $\mathrm{A} \beta$ oligomers being identified and characterized. Such oligomers have been demonstrated to exert toxic effects on synapses independently of plaque formation [5].

Despite the pivotal role posited for $\mathrm{A} \beta$ in the cause of $\mathrm{AD}$, measurements of monomeric $\mathrm{A} \beta_{42}$ in the cerebrospinal fluid (CSF) of persons with $\mathrm{AD}$ [6] or destined to develop it [7] have found it to be decreased relative to controls. It has been hypothesized that this decrement represents a shift in equilibrium from the monomeric form to oligomeric or insoluble forms in the brain, but evidence for this is indirect. A recent study found decreased $A \beta_{42}$ concurrent with elevated $A \beta$ oligomers in the CSF in a population with late-onset $\mathrm{AD}$ using an enzyme-linked immunosorbent assay (ELISA) [8].

As the pathogenic process of $\mathrm{AD}$ begins years before overt symptoms in persons carrying FAD mutations $[7,9]$, we hypothesized that $A \beta$ oligomers would be elevated in the CSF of asymptomatic FAD mutation carriers at a time when $\mathrm{A} \beta_{42}$ measured using conventional techniques would be decreased. In the current study, we measured oligomers using conformation-dependent antibodies and $A \beta_{42}$ using standard ELISA techniques in 7 asymptomatic persons at risk for developing FAD due to PSEN1 and APP mutations.

\section{Materials and Methods}

The study population consisted of the initial 7 subjects who underwent lumbar punctures in an ongoing study of clinical, imaging, and biochemical changes occurring during the presymptomatic phase of FAD. Among the 7 subjects, 2 were cousins at risk for the L235V PSEN1 mutation [10], 4 were siblings at risk for the A431E PSEN1 mutation [11], and 1 was at risk for the V717I APP mutation [12]. The subjects underwent comprehensive cognitive assessments including the Clinical Dementia Rating (CDR) [13] scale blind to their genetic status as previously described [14]. All study procedures were performed in accordance with the Helsinki Declaration of 1975 and were approved by the UCLA Institutional Review Board; all subjects provided written informed consent.

Blood was drawn and DNA extracted using standard techniques. The presence of the A431E and L235V substitutions in PSEN1 was assessed using RFLP analyses, and the presence of the V717I substitution in APP was assessed with direct sequencing. CSF was obtained and $A \beta_{42}$ levels determined using Luminex Reagents and X-MAP technology as previously described [15].

CSF samples were analyzed using dot-blot assays employing polyclonal A11 (anti-prefibrillar oligomer), OC (anti-fibrillar oligomer) and $\alpha$ APF (anti-annular protofibril) antibodies as previously described [16-18]. The total protein concentration was determined using the BCA Protein Assay kit (Pierce 23223 and 23224). The samples were diluted with PBS pH 7.4 so that all samples had equal amounts of total protein. Diluted CSF samples were spotted onto nitrocellulose membrane BA-83 (Whatman 10402495 ) at $0.9-1.6 \mu \mathrm{g}$ in $2 \mu \mathrm{l}$ and allowed to air dry. Blots were then incubated in 10\% milk in Low-Tween-TBS (20 mM Tris, 137 $\mathrm{mM} \mathrm{NaCl}, 0.01 \%$ Tween $20, \mathrm{pH}$ 7.6) for $1 \mathrm{~h}$ at room temperature. After three 5 -min washes 
Table 1. Age and CSF A $\beta_{42}$ and oligomer levels in FAD mutation carriers and noncarriers (mean \pm SD)

\begin{tabular}{lccc}
\hline & $\begin{array}{l}\text { Carriers } \\
(\mathrm{n}=5)\end{array}$ & $\begin{array}{l}\text { Noncarriers } \\
(\mathrm{n}=2)\end{array}$ & $\mathrm{p}$ \\
\hline $\begin{array}{l}\text { Age, years } \\
\text { Years younger than family-specific age of }\end{array}$ & $33 \pm 6.8$ & $30.5 \pm 2.1$ & 0.65 \\
$\quad$ dementia diagnosis & $14.4 \pm 6.3$ & $13.0 \pm 2.8$ & 0.79 \\
CSF A $\beta_{42}$, pg/ml & $260.0 \pm 144.0$ & $415.6 \pm 80.7$ & 0.22 \\
CSF A11 reactivity & $38.4 \pm 18.6$ & $22.5 \pm 4.6$ & 0.31 \\
CSF OC reactivity & $13.8 \pm 7.1$ & $3.3 \pm 1.9$ & 0.11 \\
CSF $\alpha$ APF reactivity & $70.2 \pm 10.0$ & $44.8 \pm 6.1$ & 0.02 \\
\hline
\end{tabular}

in Low-Tween-TBS, the blots were incubated overnight at $4^{\circ} \mathrm{C}$ in primary antibody solution (A11 1:2,000, $\alpha$ APF 1:1,000, and OC 1:10,000) with 5\% milk in Low-Tween-TBS, $0.02 \% \mathrm{NaN}_{3}$. After three 5-min washes, the blots were incubated in goat- $\alpha$-rabbit HRP-conjugated antibody (Jackson ImmunoResearch 305-035-0045, 1:12,000), 5\% milk in Low-Tween-TBS for $1 \mathrm{~h}$ at room temperature. Following the final three $5 \mathrm{~min}$ washes, the blots were incubated in ECL reagent (Amersham, RPN2106) for $1 \mathrm{~min}$ and exposed to film (Denville, E-3012). Oligomer concentration was quantified using densitometry as previously described [19].

The age and $A \beta_{42}, A 11, O C$, and $\alpha \mathrm{APF}$ levels were compared between mutation carriers and noncarriers using Student's t tests.

\section{Results}

Five subjects were mutation carriers (specific mutations not revealed secondary to subject confidentiality) and 2 were noncarriers. All subjects were asymptomatic (CDR scores = 0 ). The subjects did not differ in absolute age or age relative to the typical age of dementia diagnosis in their families (table 1). Levels of annular protofibrils were significantly elevated in mutation carriers relative to noncarriers (70.2 vs. $4.8, \mathrm{p}=0.02)$. Though levels of the other oligomers were not significantly different, all tended to be higher in mutation carries, whereas $\mathrm{A} \beta_{42}$ levels tended to be lower (table 1; fig. 1).

\section{Discussion}

We present initial evidence for elevated oligomers measured using conformation-dependent antibodies in the CSF of asymptomatic persons inheriting FAD mutations. Levels of $\mathrm{A} \beta_{42}$ measured using conventional immunoassays showed a trend in the opposite direction as has been well described, including in the current population $[15,20]$. Though the higher level of oligomers was not statistically significant except in the case of annular protofibrils, the consistent trend across antibodies in the context of a trend for decreased $A \beta_{42}$ suggests the possibility of oligomerization of $A \beta$ into a form not detectable by standard immunoassays for $A \beta_{42}$. These results are consistent with those of a recent report of elevated levels of annular protofibrils in the brain of AD subjects [21].

Though our conclusions are limited by the small number of subjects, our findings are consistent with the presence of an identifiable intermediate state between $A \beta_{42}$ monomers and the deposition of $A \beta_{42}$ in insoluble plaques during the presymptomatic phase of FAD. 


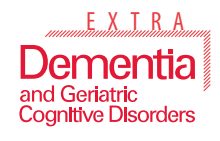

Presymptomatic Familial Alzheimer's Disease Mutation Carriers

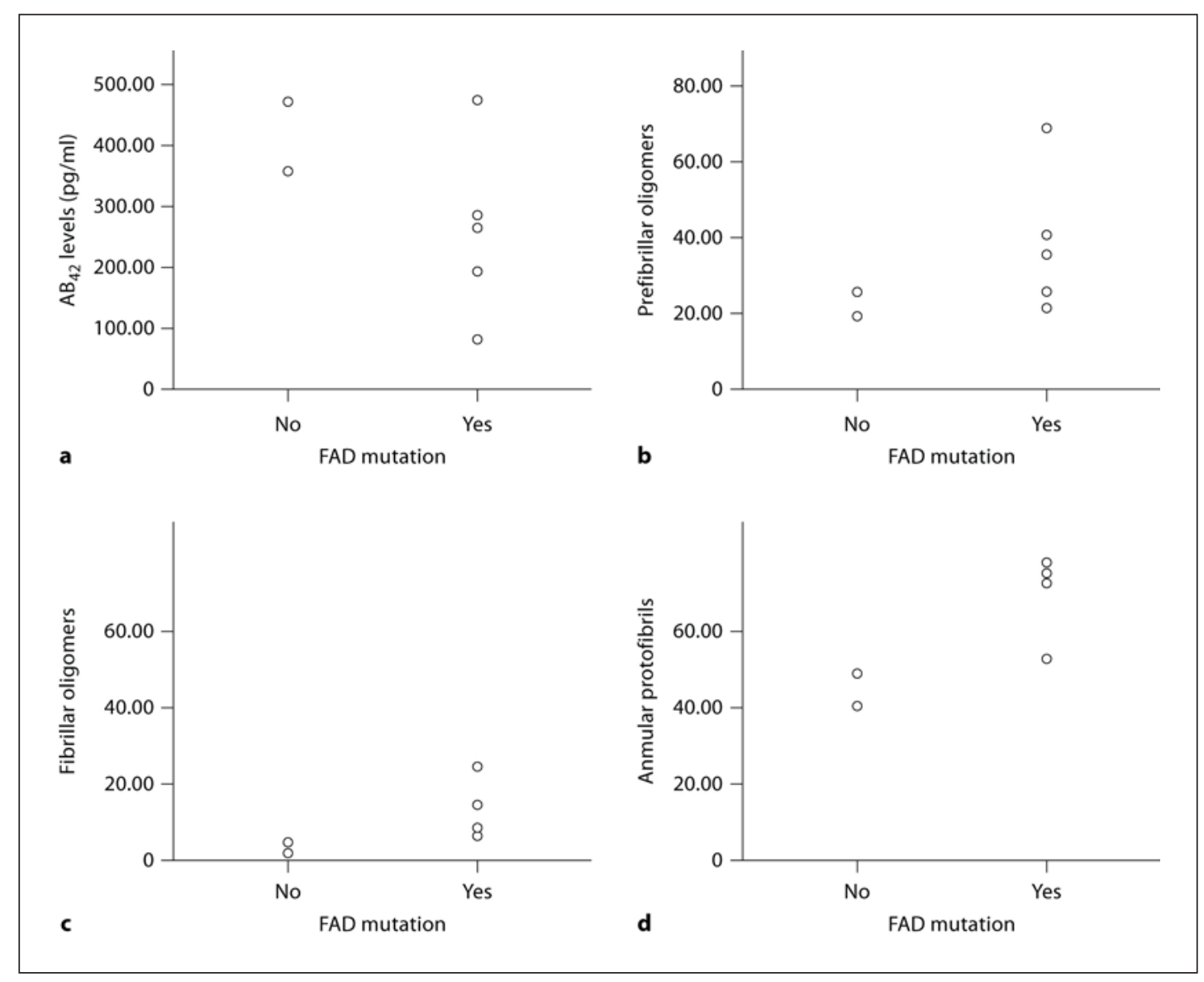

Fig. 1. CSF A $\beta_{42}$ levels measured by ELISA (pg/ml; a) and prefibrillar (b), fibrillar (c), and annular protofibrillar (d) levels (arbitrary units) in 5 FAD mutation carriers and 2 noncarriers. Annular protofibrillar levels are statistically higher in FAD mutation carriers $(\mathrm{p}=0.02)$.

Our findings are consistent with the previous observation that at least a part of the decrement of CSF $A \beta_{42}$ levels seen in AD patients is eliminated when $A \beta_{42}$ levels are measured in denaturing conditions that decrease oligomerization [22]. These results should be confirmed in larger groups of presymptomatic persons with FAD mutations as well as of those destined to develop late-onset $\mathrm{AD}$ using monoclonal conformation-dependent antibodies [23] and other techniques for measuring oligomers [8].

\section{Acknowledgements}

This study was supported by PHS K08 AG-22228, California DHS No. 04-35522, Alzheimer's Disease Research Center Grant P50 AG-16570 from the National Institute on Aging, the Easton Consortium for Alzheimer's Disease Drug Discovery and Biomarker Development, the General Clinical Research Centers Program M01-RR00865, the Sidell Kagan Foundation, and the Shirley and Jack Goldberg Trust. 
Ringman et al.: Conformation-Dependent Oligomers in Cerebrospinal Fluid of

Presymptomatic Familial Alzheimer's Disease Mutation Carriers

\section{References}

1 Hardy J, Selkoe DJ: The amyloid hypothesis of Alzheimer's disease: progress and problems on the road to therapeutics. Science 2002;297:353-356.

-2 Scheuner D, Eckman C, Jensen M, Song X, Citron M, Suzuki N, Bird TD, Hardy J, Hutton M, Kukull W, Larson E, Levy-Lahad E, Viitanen M, Peskind E, Poorkaj P, Schellenberg G, Tanzi R, Wasco W, Lannfelt L, Selkoe D, Younkin S: Secreted amyloid beta-protein similar to that in the senile plaques of Alzheimer's disease is increased in vivo by the presenilin 1 and 2 and APP mutations linked to familial Alzheimer's disease. Nat Med 1996;2:864-870.

-3 Ingelsson M, Fukumoto H, Newell KL, Growdon JH, Hedley-Whyte ET, Frosch MP, Albert MS, Hyman BT, Irizarry MC: Early Abeta accumulation and progressive synaptic loss, gliosis, and tangle formation in AD brain. Neurology 2004;62:925-931.

-4 Holmes C, Boche D, Wilkinson D, Yadegarfar G, Hopkins V, Bayer A, Jones RW, Bullock R, Love S, Neal JW, Zotova E, Nicoll JA: Long-term effects of Abeta42 immunisation in Alzheimer's disease: follow-up of a randomised, placebo-controlled phase I trial. Lancet 2008;372:216-223.

-5 Walsh DM, Klyubin I, Shankar GM, Townsend M, Fadeeva JV, Betts V, Podlisny MB, Cleary JP, Ashe $\mathrm{KH}$, Rowan MJ, Selkoe DJ: The role of cell-derived oligomers of Abeta in Alzheimer's disease and avenues for therapeutic intervention. Biochem Soc Trans 2005;33:1087-1090.

-6 Motter R, Vigo-Pelfrey C, Kholodenko D, Barbour R, Johnson-Wood K, Galasko D, Chang L, Miller B, Clark C, Green R, et al: Reduction of beta-amyloid peptide 42 in the cerebrospinal fluid of patients with Alzheimer's disease. Ann Neurol 1995;38:643-648.

-7 Ringman JM, Taylor K, Teng E, Coppola G, Gylys K: Longitudinal change in CSF biomarkers in a presymptomatic carrier of an APP mutation. Neurology 2011;78:2124-2125.

-8 Fukumoto H, Tokuda T, Kasai T, Ishigami N, Hidaka H, Kondo M, Allsop D, Nakagawa M: Highmolecular-weight beta-amyloid oligomers are elevated in cerebrospinal fluid of Alzheimer patients. FASEB J 2010;24:2716-2726.

-9 Klunk WE, Price JC, Mathis CA, Tsopelas ND, Lopresti BJ, Ziolko SK, Bi W, Hoge JA, Cohen AD, Ikonomovic MD, Saxton JA, Snitz BE, Pollen DA, Moonis M, Lippa CF, Swearer JM, Johnson KA, Rentz DM, Fischman AJ, Aizenstein HJ, DeKosky ST: Amyloid deposition begins in the striatum of presenilin-1 mutation carriers from two unrelated pedigrees. J Neurosci 2007;27:6174-6184.

-10 Janssen JC, Beck JA, Campbell TA, Dickinson A, Fox NC, Harvey RJ, Houlden H, Rossor MN, Collinge J: Early onset familial Alzheimer's disease: mutation frequency in 31 families. Neurology 2003;60:235-239.

-11 Murrell J, Ghetti B, Cochran E, Macias-Islas MA, Medina L, Varpetian A, Cummings JL, Mendez MF, Kawas C, Chui H, Ringman JM: The A431E mutation in PSEN1 causing familial Alzheimer's disease originating in Jalisco State, Mexico: an additional fifteen families. Neurogenetics 2006;7: 277-279.

-12 Mullan M, Tsuji S, Miki T, Katsuya T, Naruse S, Kaneko K, Shimizu T, Kojima T, Nakano I, Ogihara $\mathrm{T}$, et al: Clinical comparison of Alzheimer's disease in pedigrees with the codon 717 Val->Ile mutation in the amyloid precursor protein gene. Neurobiol Aging 1993;14:407-419.

$\checkmark 13$ Morris JC: Clinical dementia rating: a reliable and valid diagnostic and staging measure for dementia of the Alzheimer type. Int Psychogeriatr 1997;9(suppl 1):173-176, discussion 177-178.

-14 Ringman JM, Medina LD, Rodriguez-Agudelo Y, Chavez M, Lu P, Cummings JL: Current concepts of mild cognitive impairment and their applicability to persons at-risk for familial Alzheimer's disease. Curr Alzheimer Res 2009;6:341-346.

-15 Ringman JM, Younkin SG, Pratico D, Seltzer W, Cole GM, Geschwind DH, Rodriguez-Agudelo Y, Schaffer B, Fein J, Sokolow S, Rosario ER, Gylys KH, Varpetian A, Medina LD, Cummings JL: Biochemical markers in persons with preclinical familial Alzheimer disease. Neurology 2008;71:85-92.

- 16 Kayed R, Head E, Thompson JL, McIntire TM, Milton SC, Cotman CW, Glabe C: Common structure of soluble amyloid oligomers implies common mechanism of pathogenesis. Science 2003;300:486489.

-17 Kayed R, Head E, Sarsoza F, Saing T, Cotman CW, Necula M, Margol L, Wu J, Breydo L, Thompson JL, Rasool S, Gurlo T, Butler P, Glabe CG: Fibril specific, conformation dependent antibodies recognize a generic epitope common to amyloid fibrils and fibrillar oligomers that is absent in prefibrillar oligomers. Mol Neurodegener 2007;2:18. 
18 Kayed R, Pensalfini A, Margol L, Sokolov Y, Sarsoza F, Head E, Hall J, Glabe C: Annular protofibrils are a structurally and functionally distinct type of amyloid oligomer. J Biol Chem 2009;284:42304237.

-19 Tomic JL, Pensalfini A, Head E, Glabe CG: Soluble fibrillar oligomer levels are elevated in Alzheimer's disease brain and correlate with cognitive dysfunction. Neurobiol Dis 2009;35:352-358.

-20 Ringman JM, Coppola G, Elashoff D, Rodriguez-Agudelo Y, Medina LD, Gylys K, Cummings JL, Cole GM: Cerebrospinal fluid biomarkers and proximity to diagnosis in preclinical familial Alzheimer's disease. Dement Geriatr Cogn Disord 2012;33:1-5.

-21 Lasagna-Reeves CA, Glabe CG, Kayed R: Amyloid- $\beta$ annular protofibrils evade fibrillar fate in Alzheimer disease brain. J Biol Chem 2011;286:22122-22130.

-22 Englund H, Degerman Gunnarsson M, Brundin RM, Hedlund M, Kilander L, Lannfelt L, Pettersson FE: Oligomerization partially explains the lowering of Abeta 42 in Alzheimer's disease cerebrospinal fluid. Neurodegener Dis 2009;6:139-147.

-23 Kayed R, Canto I, Breydo L, Rasool S, Lukacsovich T, Wu J, Albay R, 3rd, Pensalfini A, Yeung S, Head E, Marsh JL, Glabe C: Conformation dependent monoclonal antibodies distinguish different replicating strains or conformers of prefibrillar A $\beta$ oligomers. Mol Neurodegener 2010;5:57. 